\title{
Study of the Form and Meaning of the Nawa Gapura Marga Raja as an Artifact of the Cirebon Cultural Community
}

\author{
Fadhly Abdillah $^{1}$, Setiawan Sabana ${ }^{2}$, Imam Santosa ${ }^{3}$ \\ Faculty of Visual Arts and Design, Institut Teknologi Bandung \\ Jl. Ganesa No. 10, Bandung, West Java, 40116 Indonesia \\ ${ }^{1}$ fadejack@students.itb.ac.id \\ 2setiawansabana@yahoo.com \\ 3imamz.santosa@gmail.com
}

\begin{abstract}
A work of traditional culture by the geniuses of Cirebon's past, named Nawa Gapura Marga Raja, is one of the historic buildings still sacred. There are nine doors or gates, each of which is gathered in one area of the building. The author's form and meaning of the number of gates is an exciting phenomenon to study, its relation to cultural expressions that allow so many symbolic values to be interpreted. This study of form and meaning aims to analyze and gain knowledge related to the form and visual meaning of the gates in this building. To find out the meaning of the physical form of Nawa Gapura Marga Raja, this study uses an art criticism approach from Edmund Burke Feldman with the visual narration method of Gerard Genette. In the process, the research goes through the following stages; literature study, observation, and conducting interviews with related parties. From the results of the analysis, it is understood that the structure of the form and layout of the building is heavily influenced by the spatial concept of primordial culture mixed with a new culture, so that it represents a myth, also has meanings that are closely related to religious teachings, culture and leadership values.
\end{abstract}

Keywords: form, art criticism, visual narrative, meaning, Nawa gapura marga raja

\section{Introduction}

In general, we can observe an artefact that is the result of the culture of a society or human. The work of these artefacts is visible (tangible) and invisible (intangible). Understanding the values in artefacts is one way for us to recognize and know the meaning implied in these physical, cultural artefacts as a reflection of subjective 
awareness between behaviour and the form of the work itself because an artistic work in the form of an artefact will not be meaningful and mean anything, without the presence of an understanding of value as subjective awareness based on the text and its context.

If we refer to sacred buildings, human cultural works in the form of temples, we can see the hierarchical spatial pattern, which is divided into sacred to profane spaces. The concept of the division of space is following the concept of religious teachings he adheres to. In the spatial concept contained in the building, its parts are limited by gates/gates with different shapes and according to their position and function. The gate is one of the building form elements that have aesthetic value and its technical function as a dividing gate between the following spaces. The form of the gate has been known before Islam entered Indonesia. The form of the gate has even been known since the Majapahit era (Hendriyana, 2007). Especially in the city of Cirebon, many gates/gates are silent witnesses of the development of Cirebon from time to time.

The establishment of the City of Cirebon cannot be separated from the historical story of the two mighty kingdoms in West Java, namely the Pakuan Padjadjaran Kingdom and the Galuh Kingdom, which is what was recorded in the Purwaka Caruban Nagari manuscript by Prince Arya Cirebon, in 1720 AD. And the term Cirebon, originally from Caruban, then Carbon, Cerbon and finally Cirebon. 
Cirebon by residents is called "Nagari Gede". Over time it is pronounced by the ordinary people "Garage" and then "Grage" (Atja, 1986). The term Cirebon roughly-base (folk etymology) is derived from Cirebon. Ci in Sundanese means water and reborn, a kind of tiny shrimp, which makes shrimp paste. This is related to the fact that Cirebon has always been a producer of shrimp, both small and large, and shrimp paste that is abundant and of good quality for export. By the guardians of Carbon called Puser Jagat, it is a country located in the middle of the island of Java (Ayatrohaedi, 2017).

The Cirebon community is a creative community that has inherited noble values from Islamic religious leaders in Java (Siti, 2011), also known as hybrid society or acculturation society. Acculturation is necessary amid the plurality of society and culture that surrounds us (Yani, 2011). This causes the city of Cirebon to be more valuable. Creating its cultural network causes the City of Cirebon to bring up often various cultural phenomena and their social transformations in a different form from mainstream cultural centres, both Sundanese and Javanese culture (and language). (Humaedi, 2013). So it got the nickname of the small Archipelago. Cirebon is a wellknown kingdom in West Java with an Islamic pattern. The Cirebon Sultanate was founded around the 15th and 16th centuries AD. Its existence is a substantial base that connects the trade routes of the islands in the archipelago. The location of the Sultanate of 
Cirebon is on the north coast of West Java which is the borderline between Central Java and West Java. This makes the Sultanate of Cirebon a bustling port and a "bridge" between 2 great cultures that blend, namely Javanese culture and Sundanese culture.

Efforts are being made to answer these questions by fulfilling the existence of the data. The data used in this study are primary and secondary. Primary data is more emphasized on the existence of ancient manuscripts that discuss the history of Cirebon, the object of Nawa Gapura Marga Raja, as well as oral history from Suwari, caretaker Nawa Gapura Marga Raja, R A. Opan Safari cultural observers, and the surrounding community. The existence of primary data is supported by secondary data in literature studies, journals, and books that discuss the gate and Cirebon. This literature review's completeness is essential in presenting data in the form of comparisons and analysis of the gates, the history of Cirebon, and the socio-politicalcultural conditions at that time.

To understand the form, meaning, and value contained in the physical form of the Nawa Gapura Marga Raja, because the Pragmatic functions and symbolic functions are factual entities that always follow following the development of these eternal objects (Whitehead, 1927).

\section{Method}

In this research, the analysis process uses an art criticism approach from Edmund Burke Feldman through several stages, including; accurate description stage, formal analysis, interpretation, and assessment (Mitleton-Kelly et al., 2018), while in the interpretation stage, the researcher added the Gerard genette visual narrative method, 
as a way to understand a more indepth analysis, namely the arrangement of the past, present and future, the result of which is that the future he expects, through the present, based on the understanding of the past he remembers.

Table 1: methodology

Arts Criticism (Edmund Burke

Feldman)

Objective Description

Formal Analysis

Interpretation

Judgment

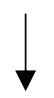

Visual Narrative (Gerard Genette)

Memory, Attention, Expectation

\section{Finding and Discussion}

\subsection{Objective Description}

Nawa Gapura Marga Raja's current position is very worrying. From left, right, and behind they are squeezed by people's houses. They claim to be courtiers of the
Kasepuhan Palace, who serve selflessly, without expecting anything in return, except for the blessings they can get from their service. To the Palace, as well as outpourings from the Sultan's Family. Precisely located in Mandalangan Village, Kasepuhan Village, Lemahwungkuk District, Cirebon City. Some parts of the large gate outside the main building have been destroyed, the top of the gate (momolo) has disappeared, some parts of the brick connecting the gate have begun to be damaged and destroyed, two white tiger statues are kneeling at the back gate, with their heads crushed, mossy, and dirty, some of the walls of the gate are black, mossy. There is a pretty wide river, and the name is the Kriyan river; this river connects Cirebon from the sea; it does not look clear, even 
the water is brownish-black, plastic waste floats, many wild plants grow around the banks of the river. Several types of trees grow near this building, motorbikes are parked carelessly, and the chicken coop is visible.

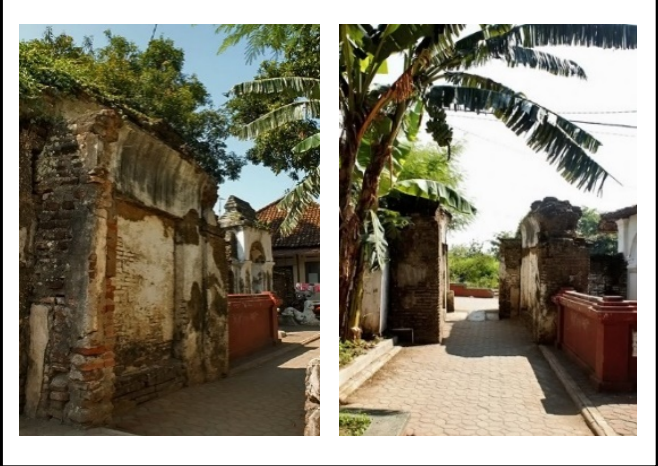

Fig. 1 Nawa Gapura Marga Raja, The position of the building which is squeezed by people's houses.

It is said that according to the elders as well as cultural observers and historians of Cirebon, this building is the first gate of the Kasepuhan Palace in 1677 AD (formerly Pakungwati Palace, 1479 AD) which overlooks the river and leads to the Java Sea. This building was initiated by Prince Wangsakerta, the younger brother of Sultan Sepuh 1

(Prince

Syamsudin Mertawijaya) and Sultan Anom 1 (Prince Badridin Kertawijaya) in the face of an important activity mandated by his father, namely compiling a script for the story of the kingdoms in the archipelago, in the form of a gotrasawala (symposium/seminar) between experts (history). ) from across the archipelago. This activity was led by Pangéran Wangsakerta and supported by the Pipitu Prosecutor. This activity was attended by approximately 77 representatives of kingdoms from all over the archipelago (Edi $\mathrm{S}$ Ekadjati, 2017) and lasted for 21 years (1677 AD - $1698 \mathrm{AD}$ ).

In fact, according to one Cirebon historian, Elang Ayi, a descendant of the Kacirebonan palace, he said that Nawa Gapura 
Marga Raja had long been built, long before the reign of Sultan Sepuh Satu, possibly along with the construction of the Palagrahan Mosque. The Kasepuhan Palace, which is named Mount Indra Kila, is a plain or bulge of land that soars upward, used as an observation and guard post.

This building consists of 9 gates/gates, with thick white walls and a tiled roof in the shape of a julang ngapak, the gate is divided into several parts with different positions, not all gates are in 1 building, there are three separate gates from the core building, among others. One main gate is in the middle of the front of the main building, five gates are located at the back of the main building, two separate gates on the right and left sides of the main building, and one other gate is separate and is at the back of the main building.

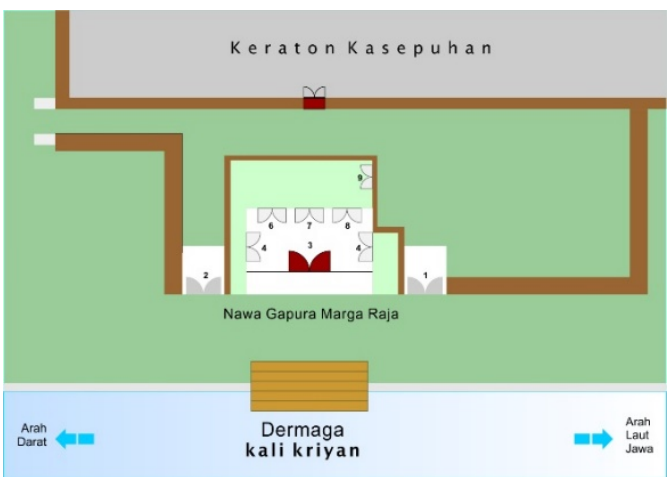

Figure 2. Plans of the Nawa Gapura Marga Raja

During the 21-year process, this building, Nawa Gapura Marga Raja, has developed its function, not only as a guard post and a gate for guests for gotrasawala activities, according to Mr Suwari (caretaker Nawa Gapura Marga Raja), also became the gateway for harbour managers from various countries, starting from China, India, Arabia, and Europe. Finally, they all mingled with the indigenous people. 


\subsection{Formal Analysis}

Nawa Gapura Marga Raja has nine irregular gates, six gates are in the main building, and three gates are outside the main building; of the six gates, one main gate is right in the middle of the front of the building facing the river, with a door big teak wood that looks fragile and has a slightly dull colour that covers it, five other gates are on the right and left rear sides and the back of the building, while two large gates are on the left and right outside the main building facing the river, and one gate is at the back of the building, with two statues of twin tigers with broken and mossy heads right at the bottom left and right of the gate, facing out.

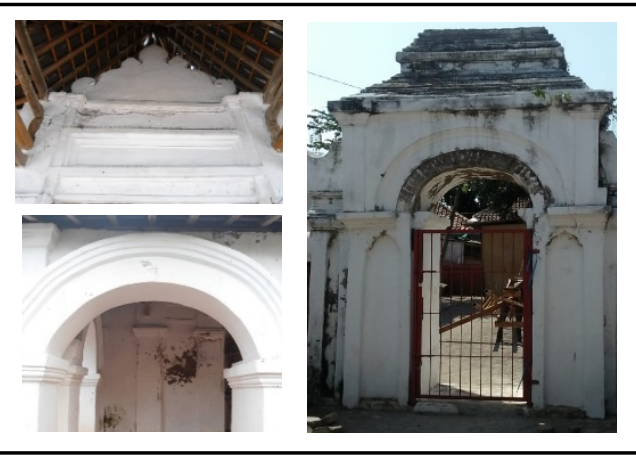

Figure 3. The Form of Nawa Gapura Marga Raja

The main building is composed of a tiled roof with a jagged shape, and there is a momolo in the form of a red brick king's crown. The thick walls are white, with a bit of moss covering some parts of the walls. The outside of the main building is surrounded by an array of red bricks, which are covered with brick walls with a red brick cart. Right on the right and left sides of the outer gate, there are stacks of thick bricks in the form of a wall, in a state of destruction, the left side of the building can be seen the remains of a red brick wall, while the right side is no longer visible, only the 
houses of residents are seen changing the position of the brick walls-crushed red.

There are two types of gates in the Nawa Gapura Marga Raja building, the inner gate of the building and the gate outside the building, the inner gate of the building is also divided into two forms, the main gate is closed with teak wood doors, and the other gate is open, while the gate on the outside is the same only in size. The two gates on the left and right sides are the same size, while the one gate at the back is more minor.

\subsection{Interpretation}

\subsubsection{Description of the} past (Memory)

Precisely in the Kasepuhan

Palace area, a majestic building stands a silent witness to the development of Cirebon from time to time, a building that requires the meaning and cultural values of the people of its time. This building is closely related to Sultan Sepuh 1; it is said that Panembahan Girilaya, the fifth Head of State of Cirebon, died in Mataram in $1662 \mathrm{AD}$, during the reign of Sultan Amangkurat I, after suffering from a severe headache during a state visit. His body was buried in Imogiri, Yogyakarta. He, from his empress, left three sons, namely: 1. Prince Martawijaya. 2. Prince Kartawijaya and 3. Prince Wangsakerta. The Cirebon Sultanate has since been divided into two, namely the Kasepuhan Sultanate and 
the Kanoman Sultanate in 1677 AD (Pakungwati Palace in $1479 \mathrm{AD}$, was built, later became the Kasepuhan Palace, while the Kanoman Palace was built in 1675 AD). Then the change was that Prince Martawijaya became the first Sepuh Sultan, with the title Sultan Raja Syamsuddin, domiciled in the Pakungwati Palace, which changed its name to the Kasepuhan Palace from generation to generation until now. Prince Wangsakerta becomes Sultan Sepuh's Assistant, domiciled in the Kasepuhan Palace with Panembahan Toh Pati (up to two generations).

Based on their shape, gates or gates can be divided into two types, namely the bentar gate and the karioagung gate. The arch of the temple bentar has a separate structure, while the karioagung gate has a unified structure, the two components of the right and left gates are combined with the shape of the head/crown of the gate. (Hendriyana, 2007).

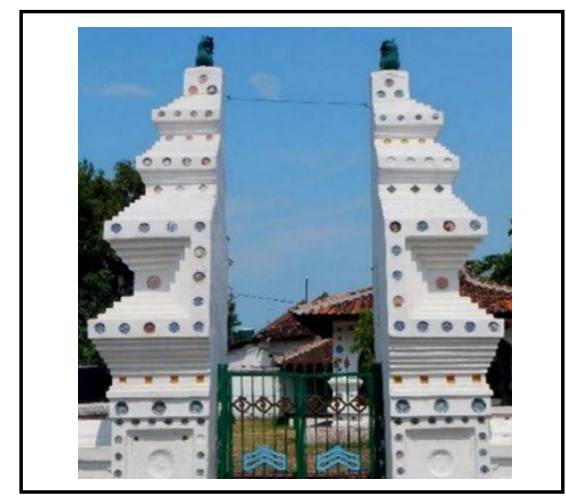

Figure 4. Bentar Form 


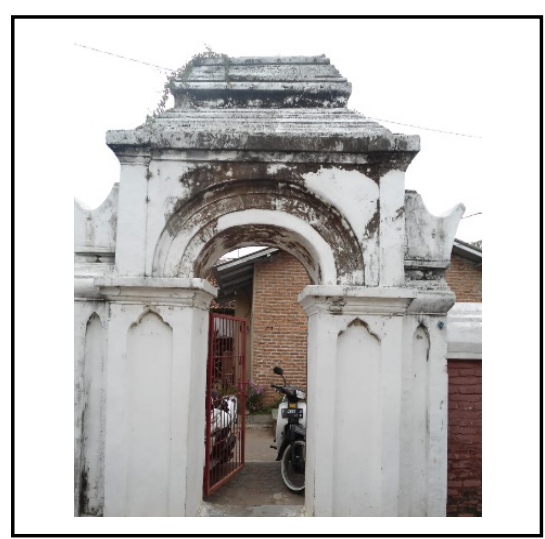

Figure 5. Karioagung Form

All forms of gates found in the Nawa Gapura Marga Raja, including the Karioagung Gate, because the structure is fused to form the head/crown of the gate, it is just that there are two parts of the large gate on the left and right of the main building that has been destroyed, so it looks like a temple gate for a while. The karioagung gate is located on the outside of the sacred space so that the Nawa gate of the king clan is included in the profane gate, the gate resulting from the concept of the culture of the people.

\subsubsection{Present Description (Attention)}

Along with the changing times, the concept of Nawa Gapura Marga Raja began to shift. The concept of a very sacred building is increasingly not felt; this building is the initial gate of the city of Cirebon through the Kasepuhan Palace. If it departs from the Dewaraja concept, the palace building occupies a sacred building. The Palace as the residence of the king, in its development, the spatial pattern of the Palace was symbolized as in the organs of the human body, which consisted of specific spaces with joint centres, and the 
spatial boundaries of the human organs were depicted in keratin buildings, as well as the new gate of the king clan, which is part of the palace building complex.

In the concept of acculturation Cirebon culture. The process of acculturation, development and even the dissemination of cultural concepts and architecture is strongly influenced by the teachings of Islam, without eliminating the concept of previous teachings, seen in the values contained in this building. In Islamic culture, especially palace buildings, gates or gates are interpreted as doors of forgiveness. Gapura is taken from the Arabic "ghofur" which means forgiveness, the shape and type of gate in the palace building are the same as the type and shape of the gate of the temple building (in the Hindu and Buddha).

Overall form too, when viewed from above, this building forms a stylization of Allah's writings, indicating that the elements of Islam played a crucial role in the construction process and the form and meaning it contains.

There are always two accompanying aspects in every human cultural artefact: physical and nonphysical aspects, tangible and intangible. These two aspects include the values of beauty that are manifested 
in the form of the Nawa

Gapura Marga Raja artefact.

To find out the values

implied in the form of the Nawa Gapura Marga Raja, it must be viewed holistically, as for the aspects of the cultural elements that influence it, consisting of primordial culture (SundaGaluh-Cirebon), HinduBuddhist and Islam (Javanese, even relations with culture). Europe can also be seen in this building). To understand the characteristics of the community's cultural life, it can be seen from the patterns of life, namely through the fabric of behaviour and objects.

\subsubsection{Future Description} (Expectation)
In transcendental culture, myth is one of the supporting factors for realizing cultural artefacts in this Gapura Marga Raja. That is related to the gate. In essence, the presence of art in classical culture rests on 3 (three) main reasons; mimesis, mythos, and praxis.

As a maritime or coastal community, Cirebon has a robust cultural openness character; the character of maritime culture is implemented in flexibility in determining spatial patterns and sacred buildings. The maritime cultural community not only recognizes two cosmic orientations, namely upstream and downstream, 
mountains and seas, left and

right of the river, facing or behind the river but also develops in a pattern consisting of (a) referring to the absolute direction/axis and (a) referring to the absolute direction/axis and ( b) refers to the relative position. The absolute axis pattern refers to the structural, and the relative position pattern refers to the hierarchical position.

Cirebon is a cultural society that conforms to the triple pattern, as seen in the concept of historic buildings that we can still see today. Society has more human relations than vertical relationships with ancestors/gods or with their God. Because the triad society considers it taboo and sacred to talk about their God in the context of daily life activities. Sri Mulyono emphasized that eastern philosophy in general and Nusantara philosophy, in particular, had never questioned God openly.

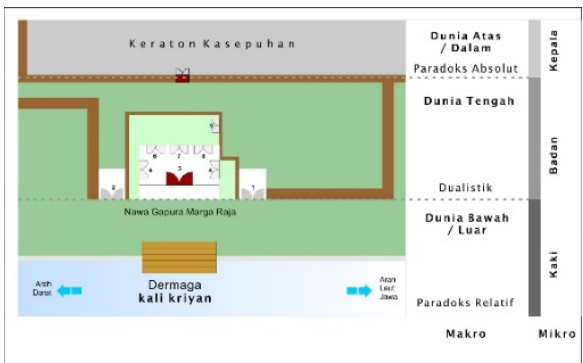

Figure 6. Three patterns cultural aesthetic structure chart

\subsection{Judgment}

The influence of cultural cosmology as the background of the cultural thinking patterns of the primordial Hindu-Buddhist society and the basic pattern of Islamic culture (religion) 
is very pronounced; even Sundanese Galuh culture is also one of the cultures behind the formation of cultural artefacts in Cirebon. Aspects of spirituality also become beliefs and beliefs as the primary foundation in cultural behaviour in social life. Even religion plays a significant role as the highest "power" in the order of the individual human; the power in question is the power of the spirituality of human behaviour. In the context of eastern culture, religion is the core and spirit of the culture. These factors support the strength of the historical

background/cultural cosmology, which ultimately underlies the concept of religious behaviour, which was widely expressed in various forms of cultural artefacts; the form of his work was an expression or representation filled with symbolic messages.

The concept of form and meaning of this building is visible; the principle of primordialism culture is seen especially in the shape and meaning of the Nawa Gapura Margaraja building, especially in the forms of the nine gates and the positions of all the gates. The karioagung gate with a crown head is typical of Hindu-Buddhist culture, with nine related to the number of Wali Sanga (Islam).

Meanwhile, the infrastructure built is a boat 
base located on the banks of the Kriyan . River (Murdihastomo \& Bauty, 2020). The Kasepuhan Palace area, founded in the 14th century, still has recognition from its "people". Although the legal aspect of the Kasepuhan Palace no longer has authority over the people, the people still recognize Sultan Sepuh as their king (Agustina et al., 2013).

The number of nine gates is also meaningful as the area that divides the sacred and profane space, the barrier between the outside world and the inside of the Palace. The number of nine gates also shows how protective the guard from the outside world is against the Palace, as a sacred world, six gates inside the main building as the main entrance for stakeholders, two gates outside the building for escorts and luggage all calculated correctly by Prince Wangsakerta.

\section{Conclusion}

Nawa Gapura Marga Raja is a gate building included in the type of "karioagung" gate because the shape structure is fused to form the head/crown of the gate. The karioagung gate is located on the outside of the sacred space (Kasepuhan palace) so that the Nawa Gapura Marga Raja is included in the profane gate, the gate resulting from the cultural concept of the community. In contrast, the building's orientation structure and spatial 
pattern as a result of the threepattern community culture are heavily influenced by a primordial cultural, spatial concept that represents a myth (a building of forgiveness). It also has a meaning that is closely related to religious teachings, culture, and leadership values. The mixing of the concepts of the primordial teachings of the people at that time, namely Hindu-Buddhist, Islam, and even Europe, resulted in the shape and meaning of the Nawa Gapura Marga Raja being very symbolic transcendentalism. Moreover, and Also Not only function as an entrance and exit and as a filter chamber (custom).

\section{Reference}

Agustina, I., Djunaedi, A., Sudaryono, S., \& Suryo, D. (2013). Gerak Ruang Kawasan Keraton Kasepuhan. Jurnal
Perencanaan Wilayah Dan Kota, 13(1), 125197.

Atja. (1986). Tjarita Purwaka Caruban Nagari. Proyek Pengembangan Permuseuman Jawa Barat.

Ayatrohaedi. (2017). Sundakala, Cuplikan Sejarah Sunda Berdasarkan Naskah-Naskah Panitia Wangsakerta Crebon (1st ed.). PT. Dunia Pustaka Jaya.

Edi S Ekadjati. (2017). Polemik Naskah Pangeran WEangsakerta. PT. Dunia Pustaka Jaya.

Hendriyana, H. (2007). Makna dan Simbol Gerbang Sembilan Astana Sunan Gunung Jati Cirebon. ITB.

Humaedi, M. A. (2013). Budaya Hibrida Masyarakat Cirebon. Humaniora, 25(3), 281-295.

Mitleton-Kelly, E., Paraskevas, A., Day, C., \& Paraskevas, P. A. (2018). Visual Methodologies. In Handbook of Research Methods in Complexity Science. https://doi.org/10.4337/97817 85364426.00017

Murdihastomo, A., \& Bauty, I. (2020). Konstruksi Sosial masyarakat Tehadap Keramik Asing di Bangunan Masjid Panjunan, Cirebon. PURBAWIDYA: Jurnal Penelitian 
Dan Pengembangan Arkeologi, 9(1), 63-78. https://doi.org/10.24164/pw.v gi1.334

Siti, K. (2011). Kearifan Lokal Pada Masyarakat Cirebon. Sosietas, 1(1). https://doi.org/10.17509/sosiet as.v1i1.1112

Whitehead, A. N. (1927). Symbolism Its Meaning and Effect ( $\mathrm{T}$. Company Macmillan (ed.); First). THE SYNDICS OF THE CAMBRIDGE UNIVERSITY PRESS.

Yani, A. (2011). Pengaruh Islam Terhadap Makna Simbolik Budaya Keraton-Keraton Cirebon. Holistik, 12(01), 16. file://C:/Users/ACER/Downlo ads/82-296-1-PB (2).pdf

Fadhly Abdillah, born in Bandung, June 23, 1977, earned a Bachelor's Degree (S.Sn.) in the Visual Communication Design Study Program, Pasundan University in 2001 and a Masters Degree (M.Ds) in the Design Study Program, Bandung Institute of Technology in 2008. I am currently pursuing further studies at the doctoral program of the Faculty of Fine Arts and Design, ITB. I work as a Lecturer in the Visual Communication Design Study Program, Pasundan University and as a teacher. Active as a member as a general secretary in AIDIA (Asosiasi Profesional Desain Komunikasi Visual Indonesia) . 
